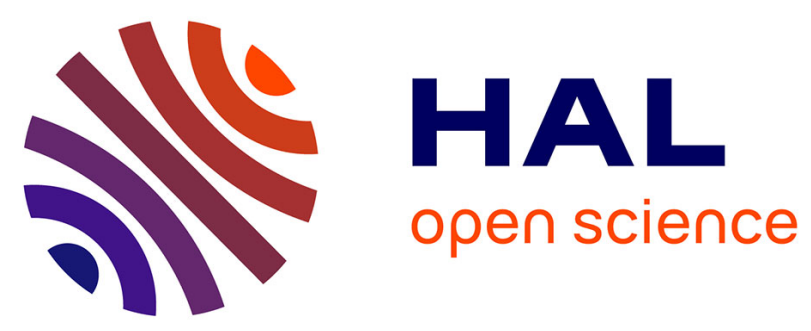

\title{
Synthesis and Anticancer Properties of Oxazepines Related to Azaisoerianin and IsoCoQuines
}

Ilhem Khelifi, Shannon Pecnard, Guillaume Bernadat, Jérôme Bignon, Hélène Levaique, Joëlle Dubois, Olivier Provot, Mouad Alami

\section{- To cite this version:}

Ilhem Khelifi, Shannon Pecnard, Guillaume Bernadat, Jérôme Bignon, Hélène Levaique, et al.. Synthesis and Anticancer Properties of Oxazepines Related to Azaisoerianin and IsoCoQuines. ChemMedChem, 2020, 10.1002/cmdc.202000197 . hal-02910295

\section{HAL Id: hal-02910295 \\ https://hal.science/hal-02910295}

Submitted on 1 Aug 2020

HAL is a multi-disciplinary open access archive for the deposit and dissemination of scientific research documents, whether they are published or not. The documents may come from teaching and research institutions in France or abroad, or from public or private research centers.
L'archive ouverte pluridisciplinaire HAL, est destinée au dépôt et à la diffusion de documents scientifiques de niveau recherche, publiés ou non, émanant des établissements d'enseignement et de recherche français ou étrangers, des laboratoires publics ou privés. 


\title{
Synthesis and Anticancer Properties of Oxazepines Related to Azaisoerianin and IsoCoQuines
}

\author{
Ilhem Khelifi, ${ }^{[a]}$ Shannon Pecnard, ${ }^{[a]}$ Guillaume Bernadat, ${ }^{[a]}$ Jérome Bignon, ${ }^{[b]}$ Hélène Levaique,${ }^{[b]}$ Joëlle \\ Dubois, ${ }^{[b]}$ Olivier Provot ${ }^{\star[a]}$, and Mouad Alami ${ }^{\star[a]}$
}

[a] Dr. I. Khelifi, S. Pecnard, Dr. G. Bernadat, Dr. O. Provot, Dr. M. Alami

Université Paris-Saclay, CNRS, BioCIS

92290 Châtenay-Malabry, France

E-mail: olivier.provot@universite-paris-saclay.fr and mouad.alami@universite-paris-aclay.fr

[b] Dr. J. Bignon, Dr. H. Levaique, Dr. J. Dubois

Institut de Chimie des Substances Naturelles, UPR 2301, CNRS

avenue de la terrasse, F-91198 Gif sur Yvette, France

Supporting information for this article is given via a link at the end of the document. ((Please delete this text if not appropriate))

\begin{abstract}
In this article, we report the synthesis and biological properties of a series of novel oxazepines related to isoCA-4 having significant antitumor properties. Among them, three oxazepin-9-ol derivatives display a nanomolar or a (sub)nanomolar cytotoxicity level against five human cancer cell lines (HCT116, U87, A549, MCF7 and K562). It was demonstrated that the lead compound in this series inhibits tubulin assembly with an $\mathrm{IC}_{50}$ value of $1 \mu \mathrm{M}$ and totally arrested the cellular cycle in the $\mathrm{G} 2 / \mathrm{M}$ phase at a low concentration of $5 \mathrm{nM}$ in HCT116 and K562 cells. Molecular modelling studies perfectly corroborates these promising results.
\end{abstract}

\section{Introduction}

Combretastatin A-4 (CA-4, Figure 1), a natural (Z)-stilbene isolated from the African willow tree Combretum caffrum by $\mathrm{G}$. Pettit ${ }^{[1]}$ in 1989 , is a very potent antimitotic agent that binds to the colchicine site on $\beta$-tubulin causing inhibition of tubulin assembly. ${ }^{[2]}$ CA-4 also displayed a nanomolar level of cytotoxicity against a wide range of human cancer cells including multidrug resistant cells (MDRs). ${ }^{[3]}$ In addition to its highly antiproliferative properties and inhibitory activity on tubulin assembly CA-4 is one of the few anti-microtubule agents reported to have a selective vascular targeting activity ${ }^{[4,5]}$ that induces an irreversible shutdown of blood flow to neoplastic cells. ${ }^{[6]}$ Its water-soluble phosphate prodrug (CA-4P, fosbretabulin, Zybrestat $^{\mathrm{TM}}$ ) has received in 2016 the orphan drug status in Europe and USA for the treatment of neuroendocrine tumors (NETs) and glioblastoma multiform (GBM) ${ }^{[7]}$ However, despite a marked efficacy in therapy, the (Z)-double bond of CA-4 and CA$4 \mathrm{P}$ isomerizes during storage, administration and metabolism to provide its 100 -fold less active (E)-isomer..$^{[8,9]}$ In an ongoing project aimed to develop stable CA-4 analogues having nonisomerizable linkers connecting the $\mathrm{A}$ - and $\mathrm{B}$ - rings, ${ }^{[10]}$ we discovered and synthesized isoCA-4 in 2009. ${ }^{[11,12]}$ This 1,1diarylethylene non-isomerizable isomer of CA-4 was found to be extremely stable and have the same biological activities as CA-4. Few years after, we demonstrated that the double bond of
isoCA-4 may be reduced or replaced by a $N$-Methyl linker to give respectively isoerianin $\left[{ }^{13]}\right.$ and azaisoerianin ${ }^{[14]}$ which likewise displayed significant antitumor properties. In this medicinal chemistry program, we have next synthesized other highly bioactive analogues through chemical modifications on the Bring of isoCA-4, and identified new stable and promising antiproliferative agents such as iso $\mathrm{NH}_{2} \mathrm{CA}-4$ and isoFCA-4, ${ }^{[15]}$ or constrained isoCA-4 derivatives of type naphthyls, ${ }^{[16]}$ chromenes, ${ }^{[17]}$ and benzoxepins. ${ }^{[18]}$ Recently, we successfully replaced for the first time, the classical 3,4,5-trimethoxyphenyl A-ring of isoCA-4 derivatives by a quinazoline or a quinoline nucleus leading to isoCombretaQuinazolines (isoCoQs), ${ }^{[19]}$ isoCombretaQuinolines (isoCoQuines) ${ }^{[20]}$ and other bioactive analogues ${ }^{[21,22]}$ having comparable or better antiproliferative activities than those of isoCA-4 and CA-4. Based on these results, Chen ${ }^{[23]}$ has combined into a single chemical structure azaisoerianin and isoCoQuines to give 4-anilinoquinolines as potent tubulin polymerization inhibitors which displayed nanomolar levels of cytotoxicity. Xie has also reported the synthesis of tetrahydro-1H-benzo[b]azepines ${ }^{[24,25]}$ as restricted analogues of Azixa ${ }^{\mathrm{TM}[26]}$ which exhibited significant in vitro cytotoxic activities $\left(\mathrm{Gl}_{50} \sim 20 \mathrm{nM}\right)$ against various cancer cell lines. Due to the success of restricted isoCA-4 analogues, ${ }^{[16-18]}$ these results encouraged us to synthesize and evaluate a novel series of benzo[b][1,4]oxazepines 1 which can be seen as constrained 4-anilinoquinoline derivatives (Figure 1) and also as structural analogues of benzo[b]azepines.

\section{Results and Discussion}

\section{Chemistry}

The target benzo[b][1,4]oxazepine 1a having no substituent on C9 $\left(R^{1}=H\right)$ was achieved from the $S_{N} A r$ reaction between 4chloroquinaldine and 2-amino-5-methoxyphenol $2 a\left(R^{2}=H\right)^{[27]}$ in hot dioxane to give diarylamine $\mathbf{3 a}$. This compound was next dialkylated in the presence of 1,3-dibromopropane and $\mathrm{NaH}$, leading to the desired benzo[b][1,4]oxazepine 1a. Next, to prepare benzo[b][1,4]oxazepines $\mathbf{1 b}$-e having a benzyloxy group 

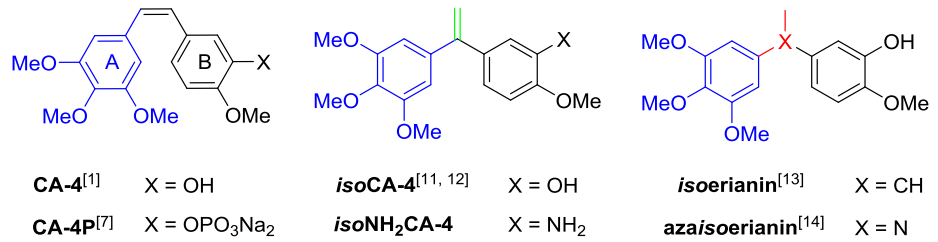

isoCA-4 ${ }^{[11,12]} \quad \mathrm{X}=\mathrm{OH}$

isoerianin $^{[13]} \quad \mathrm{X}=\mathrm{CH}$

$X=\mathrm{NH}_{2}$

azaisoerianin $^{[14]} \quad X=N$
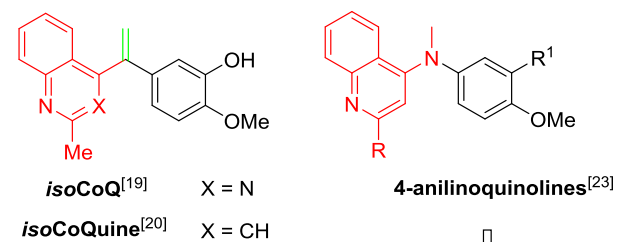

isoFCA $4 \quad \mathrm{X}=\mathrm{F}$

OMe

(Dihydro)naphtalenes ${ }^{[16]}$

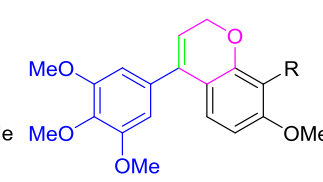

Chromenes $^{[17]}$

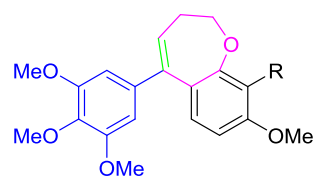

Benzoxepins $^{[18]}$

isoCoQuine $^{[20]} \quad \mathrm{X}=\mathrm{CH}$

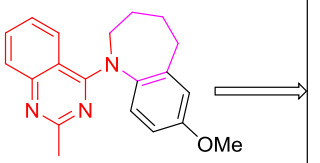

Benzo[b]azepine ${ }^{[24]}$

Azixa restricted analogue

Figure 1. Structures of CA-4, CA-4P, isoCA-4 and (restricted)-analogues, (aza)isoerianin, isoCoQ, isoCoQuine, 4-anilinoquinolines and targets benzo[b][1,4]oxazepine

on C9, we firstly synthesized amino derivative $6^{[28]}$ via a Mitsonobu reaction $\left(\mathrm{PPh}_{3}, \mathrm{DEAD}\right.$ in THF for $\left.12 \mathrm{~h}, 79 \%\right)$ between 2-(benzyloxy)-6-iodo-3-methoxyphenol $\mathbf{4}^{[29]}$ and tert-butyl (3hydroxypropyl)carbamate, which was deprotected in $\mathrm{CF}_{3} \mathrm{CO}_{2} \mathrm{H}$. Then we have fully studied the intramolecular cyclization of 6 using a variety of combinations of (I) palladium and copper catalysts $\left(\mathrm{Pd}(\mathrm{OAc})_{2}, \mathrm{Pd}_{2} \mathrm{dba}_{3}, \mathrm{Pd}\left(\mathrm{Ph}_{3}\right)_{4}, \mathrm{Cu}(\mathrm{acac})_{2}\right)$, (ii) ligands (Xantphos, $\mathrm{PPh}_{3},( \pm)$ BINAP, Xphos) and (iii) bases $\left(\mathrm{Cs}_{2} \mathrm{CO}_{3}\right.$, $\mathrm{K}_{3} \mathrm{PO}_{4}, \mathrm{NaOtBu}$ ) in hot toluene. In the majority of cases, the compound $\mathbf{6}$ was degraded or reduced upon hydrogenolysis of the $\mathrm{C}-\mathrm{I}$ bond using, for example, a mixture of $\mathrm{Pd}(\mathrm{OAc})_{2}$, Xantphos, $\mathrm{Cs}_{2} \mathrm{CO}_{3}$ in hot toluene for $28 \mathrm{~h}$ at $100{ }^{\circ} \mathrm{C}$. Fortunately, by replacing Xantphos by ( \pm ) BINAP as ligand, we have isolated after $12 \mathrm{~h}$ of reaction expected 9-(benzyloxy)-8-methoxy-2,3,4,5tetra hydrobenzo $[b][1,4]$ oxazepine 7 (yield 22\%; calculated for carbamate 5 deprotection followed by the cyclization). Then, amine derivative 7 was coupled under Pd-catalysis $\left(\mathrm{Pd}_{2} \mathrm{dba}_{3}(5\right.$ mol\%), Xantphos (10 mol\%) with various 4-chloroquinolines in the presence of $\mathrm{NaOtBu}$ to provide benzo[b][1,4]oxazepines $\mathbf{1 b}$ e with modest yields ( 16 to $41 \%$ ). These compounds were next O-debenzylated to provide benzoxepin-9-ols 1f-i using $\mathrm{AlCl}_{3}$ in DCM at rt. Following a recent work in Azixa's series, where Chen demonstrated the utility of a 2-chloroacetate function in place of the traditional $\mathrm{OH}$ substituent, ${ }^{[23]}$ we have also synthesized benzo[b][1,4]oxazepine $\mathbf{1 j}$ by mixing $1 \mathbf{1 f}$ with 2 chloroacetyl chloride in the presence of $\mathrm{NEt}_{3}$.

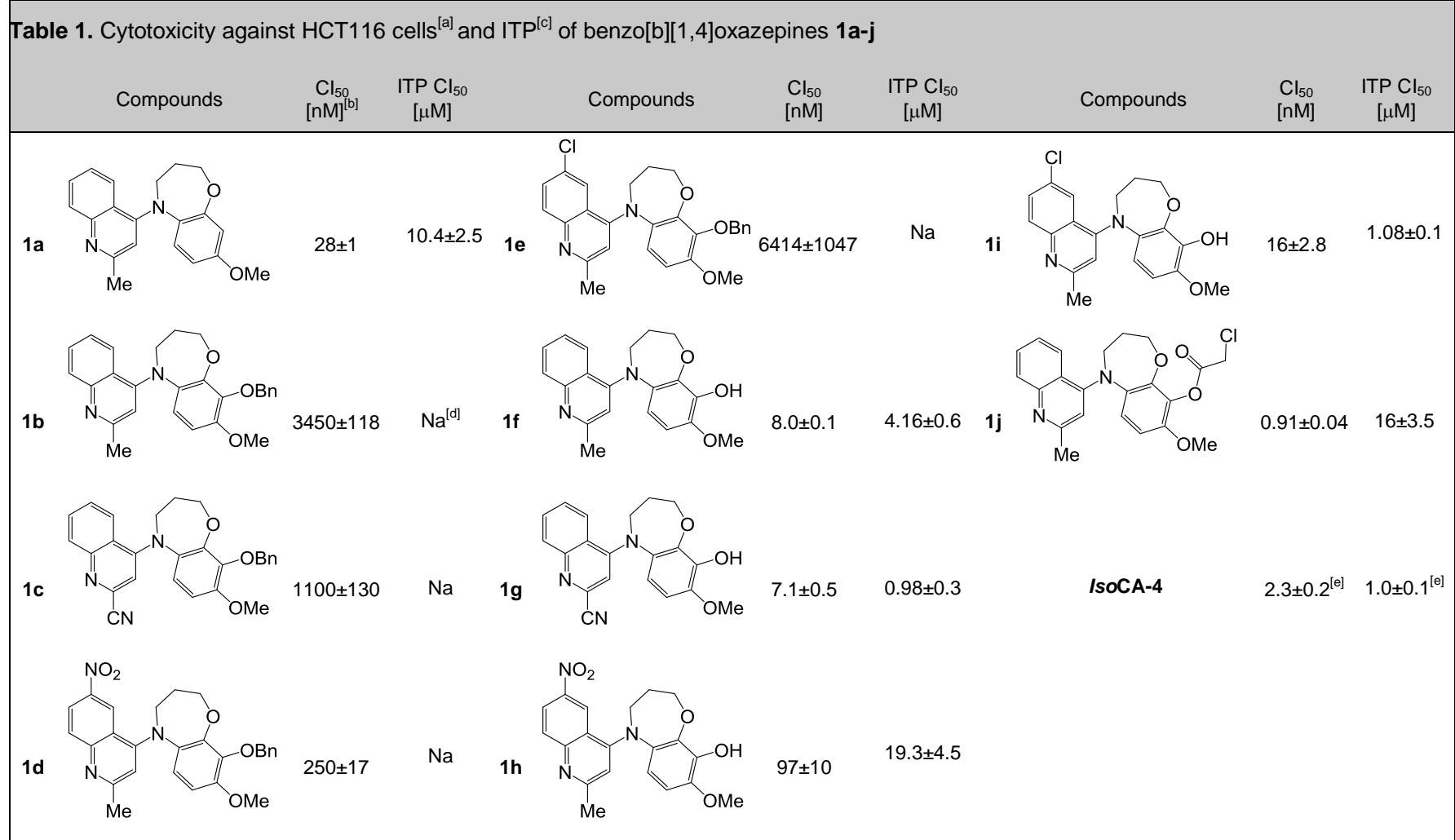

[a] HCT116 human colon carcinoma [b] $\mathrm{IC}_{50}$ is the concentration of compound needed to reduce cell growth by $50 \%$ following $72 \mathrm{~h}$ cell treatment with the tested drug; for $\mathrm{IC}_{50}$ determination, all products $1 \mathrm{a}-\mathrm{j}$ were tested at 10 different concentrations, each concentration being tested in triplicate.[c] ITP (Inhibition of Tubulin Polymerization) $I_{50}$ is the concentration of compound required to inhibit $50 \%$ of the rate of 
<smiles>COc1ccc(N)c(O)c1</smiles>

$2 a$<smiles>COc1ccc(Nc2cc(C)nc3ccccc23)c(O)c1</smiles>

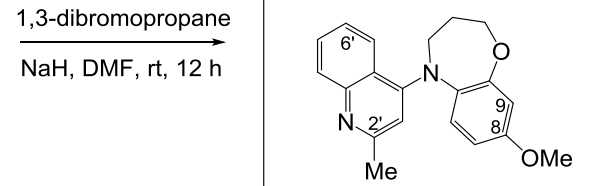

Benzo[b][1,4]oxazepine 1a<smiles>COc1ccc(I)c(O)c1OCc1ccccc1</smiles>
4 5<smiles>COc1ccc2c(c1OCc1ccccc1)OCCCN2c1ccc(OC)c2c1OCCCN2c1cc(C)nc2cc(OCc3ccccc3)c(OC)c(OC)c12</smiles>
1c<smiles>COc1ccc(N2CCCOc3c4cccc-4nc(C#N)cc32)c(OCc2ccccc2)c1</smiles><smiles>COc1ccc2c(c1OCc1ccccc1)OCCCN2c1cc(C)nc2ccccc12</smiles>

$1 \mathrm{~b}$<smiles>CCN(CC)CCOc1c(OC)ccc2c1OCCCN2c1cc(C)nc2ccccc12</smiles>

1j<smiles>COc1ccc2c(c1O)OCCCN2c1cc(C)nc2ccccc12</smiles>

$1 f$

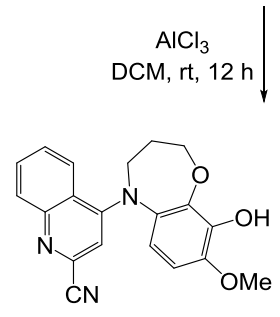

$1 \mathrm{~g}$<smiles>COc1ccc2c(c1O)OCCCN2c1cc(C)nc2ccc([N+](=O)[O-])cc12</smiles>

$1 \mathrm{~h}$

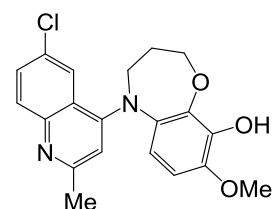

$1 i$

Scheme 1. Synthesis of target benzo[b][1,4]oxazepines 1a-j.

\section{Biology}

(A) In vitro cell growth assay and inhibition of tubulin polymerization

In vitro cytotoxicity of synthesized benzo[b][1,4]oxazepines 1a-j was evaluated against human colon carcinoma (HCT116) cell line (Table 1). A fluorimetry-based assay was used for determination of the drug concentration required to inhibit cell growth by $50 \%$ after incubation in the culture medium for $72 \mathrm{~h}$. IsoCA-4 ${ }^{[30]}$ was included as reference compound for comparisons.

As it can be observed, all benzoxazepines $1 \mathrm{~b}$-e having a benzyloxy-function on C9 display a modest micromolar level of cytotoxicity on HCT116 cells, except $\mathbf{1 d}\left(\mathrm{IC}_{50}=250 \mathrm{nM}\right)$. These results are the consequence of a too large congestion on $\mathrm{C9}^{\left[{ }^{[31]}\right.}$ This observation was confirmed by the cytotoxicity level of oxazepine 1a having no substituent on $\mathrm{C9}$, which display a promising level of cytotoxicity $\left(\mathbf{1 a}, \mathrm{IC}_{50}=28 \mathrm{nM}\right)$. Comparison of antiproliferative properties of oxazepin-9-ol derivatives $\mathbf{1 f}$ and $\mathbf{1 g}$ revealed that a hydroxy-function on C9 increase the level of cytotoxicity and that $-\mathrm{Me}$ and $-\mathrm{CN}$ groups on $\mathrm{C} 2$ of the quinoline nucleus led to comparable cytotoxic agents $\left(\mathrm{IC}_{50}\right.$ values $=8$ and $7 \mathrm{nM}$, respectively for $\mathbf{1 f}$ and $\mathbf{1 g}$ ). We noticed that a chlorine atom or a nitro-group on the $\mathrm{C} 6$ position of the quinoline nucleus did not improve the cytotoxicity of oxazepin-9-ols $\mathbf{1 h}$ and $\mathbf{1 i}$, which does not exclude that their chemical transformation could lead to highly cytotoxic compounds. Finally, esterification of the phenol function of 1 if by 2-chloroacetyl chloride improve the cytotoxicity level, since ester $\mathbf{1 j}\left(\mathrm{IC}_{50}=0.9 \mathrm{nM}\right)$ was found to be $\sim 9$-fold more cytotoxic against HCT116 cells than oxazepin-9-ol 16.

To investigate whether these derivatives were exerting their activity by interactions with microtubules, all benzo[b][1,4]oxazepines 1 were evaluated for their anti-tubulin activities. The inhibition of tubulin polymerization (ITP) results of benzo[b][1,4]oxazepines 1a-j presented in Table 1 indicate that the most cytotoxic benzo[b][1,4]oxazepin-9-ols $\mathbf{1 f}, \mathbf{g}$ and $\mathbf{1 i}$ were the more potent inhibitors of tubulin assembly with micromolar

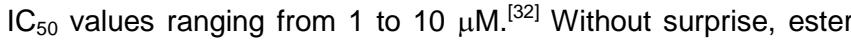
derivative $1 \mathbf{j}$ (found as the more cytotoxic derivative against HCT116 cells), exhibited an $\mathrm{IC}_{50}$ value against tubulin of $16 \mu \mathrm{M}$, substantially weaker than those of oxazepin-9-ols 1 if $\left(\mathrm{IC}_{50}=4\right.$ $\mu \mathrm{M})$ and $\mathbf{1 g}\left(\mathrm{IC}_{50}=1 \mu \mathrm{M}\right)$ because the anti-tubulin evaluation was achieved using a purified tubulin devoid of esterases. ${ }^{[12]}$ One also can note that the best inhibitor of tubulin assembly in this series is oxazepin-9-ol $\mathbf{1 g}$ having a $\mathrm{CN}$-function on $\mathrm{C} 2$. Oxazepin-9-ol $\mathbf{1 g}$ was found a comparable inhibitor of tubulin polymerization to isoCA-4 and 4-times more potent than quinaldine 1f. These preliminary biological results demonstrate that benzo[b][1,4]oxazepin-9-ols $\mathbf{1 f}, \mathbf{g}$ and ester derivative $\mathbf{1 j}$ are promising candidates in this novel series of constrained derivatives.

We next investigated the effect on the proliferation of oxazepin9-ols $\mathbf{1 f}, \mathbf{1 g}$ and $\mathbf{1 j}$ on other cell lines as human glioblastoma cells (U87), human lung epithelial cells (A549), human breast adenocarcinoma cell lines (MCF7) and chronic myeloid leukemia 
cells in blast crisis (K562). The results of this study are depicted in Table 2 and reveal that selected oxazepin-9-ols $\mathbf{1 f}, \mathbf{g}$ and $\mathbf{1 j}$ are highly cytotoxic against all tested cancer cells.

Table 2. Cytotoxicity against human cancer cell lines, U87, A549, MCF7, K562 and HCT116

\section{Cytoxicity $\mathrm{IC}_{50},(\mathrm{nM})^{[\mathrm{a}]}$}

\begin{tabular}{|cccccc|}
\hline Compound & $\mathrm{U} 87^{[\mathrm{b}]}$ & $\mathrm{A} 549^{[\mathrm{c}]}$ & $\mathrm{MCF} 7^{[\mathrm{d}]}$ & $\mathrm{K} 562^{[\mathrm{e}]}$ & $\mathrm{HCT} 116^{[\mathrm{f}]}$ \\
\hline $\mathbf{1 f}$ & $1.27 \pm 0.40$ & $9.64 \pm 0.65$ & $4.5 \pm 0.3$ & $3.10 \pm 0.21$ & $8.00 \pm 0.01$ \\
$\mathbf{1 g}$ & $0.24 \pm 0.11$ & $2.33 \pm 0.71$ & $32 \pm 3$ & $0.94 \pm 0.01$ & $7.0 \pm 0.05$ \\
$\mathbf{1 j}$ & $2.82 \pm 0.49$ & $3.17 \pm 0.10$ & $30 \pm 2$ & $3.25 \pm 0.02$ & $0.91 \pm 0.04$ \\
$\begin{array}{c}\text { Iso } \\
\text { CA-4 }\end{array}$ & $7.8 \pm 0.06$ & $8.2 \pm 0.7$ & $3 \pm 0.2$ & $1.0 \pm 0.1$ & $2.3 \pm 0.2$ \\
\hline
\end{tabular}

[a] $\mathrm{IC}_{50}$ is the concentration of ozaxepines $\mathbf{1}$ needed to reduce cell growth by $50 \%$ following $72 \mathrm{~h}$ cell treatment with the tested drug; For $\mathrm{IC}_{50}$ determination, $\mathbf{1 f}, \mathbf{1} \mathbf{g}$ and $\mathbf{1} \mathbf{j}$ were tested at different concentrations, each concentration being tested in triplicate. [b] U87 Human glioblastoma cells. [c] A549, human lung epithelial cells. [d] MCF7 human breast adenocarcinoma cell line. [e] chronic myeloid leukemia cells in blast crisis. [f] HCT116 human colon carcinoma.

Except on HCT116 cells, which were used for the preliminary screening evaluation, oxazepin-9-ol $\mathbf{1 f}$ and its ester derivative $\mathbf{1 j}$ displayed a better level of cytotoxicity against U87 and MCF7 cancer cell lines. Oxazepin-9-ol $\mathbf{1 g}$ was clearly the more cytotoxic derivative in this series against all tested cancer cells and particularly against U87 and MCF7 cells with $\mathrm{IC}_{50}$ values of 0.24 and $0.43 \mathrm{nM}$, respectively. This study reveal that, when compared to isoCA-4, oxazepin-9-ol $\mathbf{1 g}$ is 32-fold more cytotoxic against U87 cells, 3.5-fold more cytotoxic against A549 cells and 19-fold more cytotoxic against MCF7 cells. These results suggests that oxazepin-9-ols $\mathbf{1 f}, \mathbf{1} \mathbf{j}$ and especially $\mathbf{1 g}$ are promising candidates in this novel series of 4anilinoquinoline constrainted derivatives.

\section{(B) Cell cycle distribution}

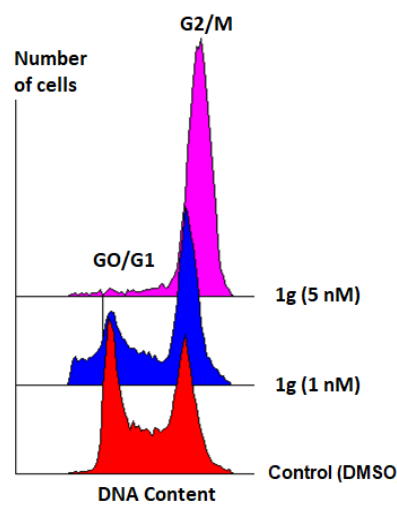

(A)

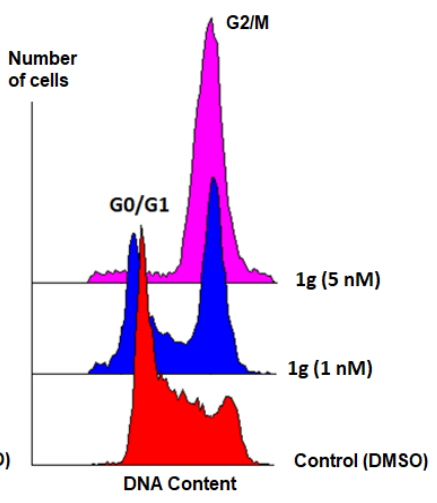

(B)
Figure. 2. Effect of $\mathbf{1 g}$ on cell cycle distribution in HCT116 (A) and K562 (B) cells determined by flow cytometry analysis. DNA content was assessed via propidium iodide staining.
Oxazepin-9-ol 1g, which displayed against the five cancer cell lines the better cytotoxicity level $\left(0.24 \mathrm{nM}<\mathrm{IC}_{50}<7 \mathrm{nM}\right)$, was next tested in dose-response experiments using HCT116 and K562 cells on cell cycle distribution. ${ }^{[33]}$ HCT116 and K562 cells were treated for $24 \mathrm{~h}$ with increasing concentrations (1 and 5 $\mathrm{nM}$ ) of $1 \mathrm{~g}$ and DMSO was used as control. As can be seen in Fig. 2, oxazepin-9-ol $\mathbf{1 g}$, at a concentration of $5 \mathrm{nM}$, has arrested the entire population of HCT116 and K562 cells in the $\mathrm{G} 2 / \mathrm{M}$ phase of the cellular cycle, similarly to those of isoCA-4. ${ }^{[12]}$ These observations consolidate our idea that $\beta$-tubulin is certainly one of the targets of $\mathbf{1 g}$ and other benzoxazepins.

\section{(C) Docking study}

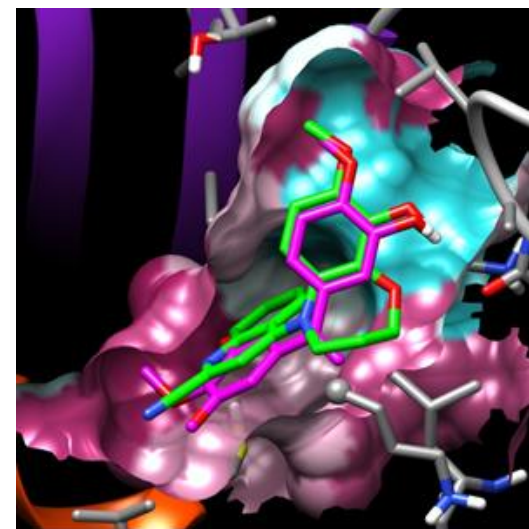

(A)

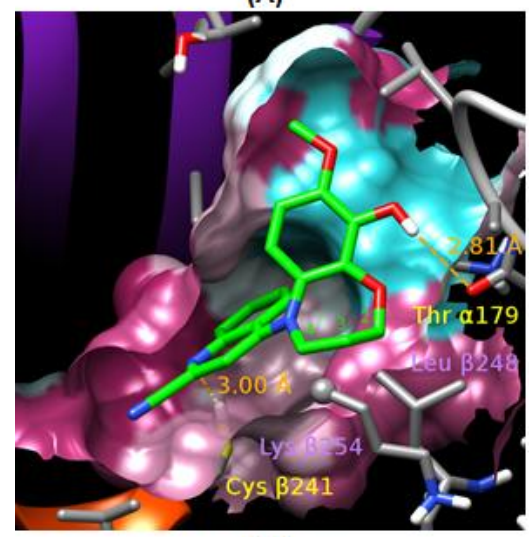

(B)

Figure 3. (A) Putative binding mode of oxazepin-9-ol 1g (green color) within colchicine binding site of tubulin X-ray structure (accession code 6H9B) 1) with previously reported binding mode of reference compound isoCA-4 in overlay (magenta color). (B) Same figure (without isoCA-4 reference binding mode) showing expected hydrogen bonds between ligand atoms and cysteine $\beta 241$ and threonine $\alpha 179$ protein residues and proximity between seven-membered ring hydrophobic part and side chains of lysine $\beta 254$ (represented in the front, starting from beta carbon as larger grey color atom) and leucine $\beta 248$.

Figure 3 presents the results of molecular docking calculations of the structure of oxazepin-9-ol $\mathbf{1 g}$ within the colchicine binding site of tubulin $\beta$ subunit (the structure of which was obtained from X-ray crystal structure with accession code $6 \mathrm{H} 9 \mathrm{~B}$ ). The overall binding mode observed match that previously known for isoCA-4 (see overlay on subfigure A), with the quinoline ring system being accomodated by the lipophilic pocket ordinarily occupied by the 3,4,5-trimethoxyphenyl nucleus, as well as the substituted aromatic ring belonging the tetrahydrobenzooxazepin ring sitting at the same place as the B-ring of isoCA-4. Interactions that can be expected given this binding mode hypothesis include notably (see subfigure B) two potential 
hydrogen bonds: one between the side-chain $\mathrm{SH}$ group of the cysteine $\beta 241$ residue and the endocyclic nitrogen atom of the quinoline moiety and the other between the hydroxy group belonging to the ligand and backbone carbonyl group of threonine $\alpha 179$. The contribution of these point interactions to the overall binding are reinforced by the contact between the $\mathrm{C} 2$ carbon atom of the seven-membered ring and the hydrophobic side chain of leucine $\beta 248$, as well as between the C3 and C4 carbon atoms of the same ring and the hydrophobic part of the side chain of lysine $\beta 254$. The docking-derived superimposition of $1 \mathrm{~g}$ with isoCA-4 show a binding pose comparable to the one observed with isoCA-4. As it was previously observed with isoCoQs, the nitrogen atom of the quinoline ring of $\mathbf{1 g}$ is placed in proximity of Cys241 and the -OH group on $\mathrm{C} 9$ in proximity of Val181 to establish a hydrogen bond. All these biological results suggest that oxazepin-9-ol $\mathbf{1 g}$ might be a lead compound for use as a vascular disrupting agent and a promising candidate for in vivo evaluation.

\section{Conclusion}

In summary, we have synthesized a series of benzoxazepines 1a-j which were obtained by the Pd-coupling of 2,3,4,5tetrahydrobenzo[b][1,4]oxazepine $\mathbf{7}$ with 4 -chloroquinolines followed by a debenzylation step. All oxazepines were evaluated for their antiproliferatives properties and cytotoxicity results showed that oxazepines having a free $\mathrm{OH}$ on $\mathrm{C} 9$ (oxazepin-9ols) displayed the best nanomolar cytotoxicities levels against human cancer cell lines and inhibited the tubulin assembly into microtubules. Among these oxazepines, oxazepin-9-ol $\mathbf{1 g}$ having a $\mathrm{CN}$-group on $\mathrm{C} 2$, a $-\mathrm{OH}$ on $\mathrm{C} 9$ and a $-\mathrm{OMe}$ on $\mathrm{C} 8$ appears to be the most promising agent in this series with subnanomolar $\mathrm{IC}_{50}$ values on various human cancer cells. Oxazepin-9-ol $\mathbf{1 g}$ is 32 -fold more cytotoxic than isoCA-4 against U87 cells and $\sim 20$-fold more cytotoxic against MCF7 cells. Moreover, we have also shown that, after $24 \mathrm{~h}$ of treatment using oxazepin-9-ol 1g, K562 and HCT116 cells were totally arrested in the G2/M phase at a low concentration of $5 \mathrm{nM}$ as it was observed with other isoCA-4 derivatives. ${ }^{[12,16]}$

\section{Experimental Section}

\section{Chemistry}

\section{General considerations}

The compounds were all identified by usual physical methods, i.e. ${ }^{1} \mathrm{H}$ NMR, ${ }^{13} \mathrm{C}$ NMR, IR, HRMS. ${ }^{1} \mathrm{H},{ }^{13} \mathrm{C}$ and spectra were measured in $\mathrm{CDCl}_{3}$ with a Bruker $\mathrm{AMX} 200\left({ }^{1} \mathrm{H}\right.$, and $\left.{ }^{13} \mathrm{C}\right)$ or with a Bruker Avance $300\left({ }^{1} \mathrm{H}\right.$ and $\left.{ }^{13} \mathrm{C}\right) .{ }^{1} \mathrm{H}$ chemical shifts are reported in ppm from an internal standard TMS or of residual chloroform (7.27 ppm). The following abbreviations are used: $m$ (multiplet), $s$ (singlet), $d$ (doublet), $\mathrm{t}$ (triplet), quin (quintet). ${ }^{13} \mathrm{C}$ chemical shifts are reported in ppm from the central peak of $\mathrm{CDCl} 3$ (77.14). IR spectra were measured on a Bruker Vector 22 spectrophotometer (neat, $\mathrm{cm}^{-1}$ ). Melting points (m.p.) were recorded on a Büchi B-450 apparatus and were uncorrected. Mass spectra were obtained with a LCT Micromass spectrometer. Analytical TLC was performed on Merck pre-coated silica gel 60F plates. Merck silica gel 60 (230-400 mesh) was used for column chromatography.
Procedure for the synthesis of new compounds

t-Butyl (3-(2-(benzyloxy)-6-iodo-3-methoxyphenoxy)propyl) carbamate $5(79 \%)$

2-(Benzyloxy)-6-iodo-3-methoxyphenol (3.2 g, $8.8 \mathrm{mmol}$ ) was mixed with t-butyl (3-hydroxypropyl)carbamate $(1.4 \mathrm{~g}, 8 \mathrm{mmol})$ and $\mathrm{PPh}_{3}$ $(3.0 \mathrm{~g}, 11.2 \mathrm{mmol})$ in dry THF $(16 \mathrm{~mL})$. At $0{ }^{\circ} \mathrm{C}$, DEAD $(1.72 \mathrm{~mL}$, $11.2 \mathrm{mmol}$ ) was added to the solution which was stirred for $12 \mathrm{~h}$ at $0{ }^{\circ} \mathrm{C}$. Water was added to the mixture before extraction with EtOAc $(3 \times 10 \mathrm{~mL})$. Organic phases were dried over sodium sulfate, filtered and evaporated. After concentration under reduced pressure, the crude mixture was purified by chromatography on silica gel eluting with cyclohexane/ethyl acetate (95:5) to give 5 (3.2 g, 79\%) as a brown oil.

Brown oil (3.2 g, 79\%). ${ }^{1} \mathrm{H}$ NMR $\left(300 \mathrm{MHz}, \mathrm{CDCl}_{3}\right) \delta 7.37-7.22(\mathrm{~m}$, $7 \mathrm{H}), 6.41(\mathrm{~d}, J=8.8 \mathrm{~Hz}, 1 \mathrm{H}), 4.90(\mathrm{~s}, 2 \mathrm{H}), 3.96(\mathrm{t}, J=5.8 \mathrm{~Hz}, 2 \mathrm{H})$, 3.72 (s, 3H), 3.27 (t, $J=5.2 \mathrm{~Hz}, 2 \mathrm{H}$ ), 1.80 (quin, $J=5.2 \mathrm{~Hz}, 2 \mathrm{H}$ ), $1.33(\mathrm{~s}, 9 \mathrm{H}) .{ }^{13} \mathrm{C}$ NMR $\left(75 \mathrm{MHz}, \mathrm{CDCl}_{3}\right) \delta 156.0,154.7,152.7,141.8$, 137.2, 132.9, 128.4 (2), 128.3 (2), 128.2, 110.1, 81.7, 78.9, 75.6, $71.7,56.2,38.0,30.2,28.5$ (3). IR neat $v \max / \mathrm{cm}^{-1}: 3353,2925,1313$, 1297. HRMS calcd for $\mathrm{C}_{22} \mathrm{H}_{29} \mathrm{INO}_{5}[\mathrm{M}+\mathrm{H}]^{+}:$514.1090., obsd 514.1071.

\section{9-(Benzyloxy)-8-methoxy-2,3,4,5-tetrahydrobenzo [b] [1,4]oxazepine 7 (22\% for the two steps)}

To a solution of $5(1.13 \mathrm{~g}, 2.20 \mathrm{mmol})$ in DCM $(120 \mathrm{~mL})$ was added slowly TFA $(5 \mathrm{~mL})$ at rt. After $30 \mathrm{~min}$. of stirring, the mixture was neutralized with $\mathrm{NaOH}(1 \mathrm{~N})$ until $\mathrm{pH}=7$. After extraction with EtOAc ( $3 \times 40 \mathrm{~mL})$, drying on sodium sulfate, filtration and concentration, the crude product 6 was dissolved in toluene $(30 \mathrm{~mL})$. The solution was stirred at $130{ }^{\circ} \mathrm{C}$ for $12 \mathrm{~h}$ in a sealed tube with $\mathrm{Pd}_{2} \mathrm{dba}_{3}-\mathrm{CHCl}_{3}$ (100 mg, $0.1 \mathrm{mmol}),( \pm)$-BINAP (120 mg, $0.2 \mathrm{mmol}$ ) and $\mathrm{Cs}_{2} \mathrm{CO}_{3}$ $(1.44 \mathrm{~g}, 4.4 \mathrm{mmol})$. After cooling, the solution was filtered on a pad of celite and concentrated. The crude mixture was purified by chromatography on silica gel eluting with cyclohexane/ethyl acetate (95:5) to give 7 (137 $\mathrm{mg}, 22 \%)$ as a brown oil.

Brown oil (137 mg, 22\%). ${ }^{1} \mathrm{H}$ NMR $\left(300 \mathrm{MHz}, \mathrm{CDCl}_{3}\right) \delta 7.40-7.31$ $(\mathrm{m}, 5 \mathrm{H}), 6.50(\mathrm{~d}, J=7.2 \mathrm{~Hz}, 1 \mathrm{H}), 6.47(\mathrm{~d}, J=7.1 \mathrm{~Hz}, 1 \mathrm{H}), 5.07$ (s, $2 \mathrm{H}$ ), 4.00 (t, $J=5.6 \mathrm{~Hz}, 2 \mathrm{H}), 3.81(\mathrm{~s}, 3 \mathrm{H}), 3.16(\mathrm{t}, J=5.6 \mathrm{~Hz}, 2 \mathrm{H})$, $2.00(\mathrm{q}, J=5.6 \mathrm{~Hz}, 2 \mathrm{H})$, NH not seen. ${ }^{13} \mathrm{C} \mathrm{NMR}\left(75 \mathrm{MHz}, \mathrm{CDCl}_{3}\right) \delta$ 148.1, 145.9, 141.3, 138.3, 137.8, 128.5 (2), 128.3 (2), 127.8, 113.6, 107.4, 75.6, 72.2, 56.8, 46.7, 32.5. IR neat $\mathrm{vmax} / \mathrm{cm}^{-1}: 3445,2910$, 1510, 1231. HRMS calcd for $\mathrm{C}_{17} \mathrm{H}_{20} \mathrm{NO}_{3}[\mathrm{M}+\mathrm{H}]^{+}:$286.1443., obsd 286.1446 .

8-Methoxy-5-(2-methylquinolin-4-yl)-2,3,4,5-tetrahydro benzo[b][1,4] oxazepine 1a (37\% for the two steps)

In a sealed tube were successively added 4-chloroquinaldine $(89 \mathrm{mg}$, $0.5 \mathrm{mmol}$ ), 2-amino-5-methoxyphenol $(70 \mathrm{mg}$ ) and one drop of $\mathrm{HCl}$ $(12 \mathrm{~N})$ in 1,4-dioxane $(2 \mathrm{~mL})$. The mixture was then stirred for $16 \mathrm{~h}$ at $140{ }^{\circ} \mathrm{C}$. After cooling, the solution was neutralized with $\mathrm{NaOH}(5 \mathrm{~N})$ until $\mathrm{pH}=7$ and extracted with EtOAc $(3 \times 10 \mathrm{~mL})$. Organic phases were dried over sodium sulfate, filtered and evaporated. The crude product 3a was dissolved at $0{ }^{\circ} \mathrm{C}$ in DMF $(3 \mathrm{~mL})$ containing $\mathrm{NaH}$ $60 \%$, (96 mg, $2.5 \mathrm{mmol}$ ). 1,3-Dibromopropane (500 mg, $2.5 \mathrm{mmol}$ ) was slowly added to the mixture which was stirred at it for $2 \mathrm{~h}$. After concentration under reduced pressure, the crude mixture was purified by chromatography on silica gel eluting with cyclohexane/ethyl acetate $(95: 5)$ to give 1 a $(59 \mathrm{mg}, 37 \%)$ as a yellow solid.

Yellow solid (59 mg, 37\%), m.p. = 89.7 - 92. $1^{\circ} \mathrm{C} .{ }^{1} \mathrm{H}$ NMR $(300 \mathrm{MHz}$, $\left.\mathrm{CDCl}_{3}\right) \delta 7.97(\mathrm{~d}, J=8.4 \mathrm{~Hz}, 1 \mathrm{H}), 7.59(\mathrm{~d}, J=8.6 \mathrm{~Hz}, 1 \mathrm{H}), 7.53(\mathrm{~d}, J$ 
$=7.1 \mathrm{~Hz}, 1 \mathrm{H}$ ), 7.20 (t, $J=7.7 \mathrm{~Hz}, 1 \mathrm{H}), 6.92(\mathrm{~s}, 1 \mathrm{H}), 6.69(\mathrm{~d}, J=2.8$ $\mathrm{Hz}, 1 \mathrm{H}), 6.48(\mathrm{~d}, J=8.8 \mathrm{~Hz}, 1 \mathrm{H}), 6.34(\mathrm{dd}, J=8.8 \mathrm{~Hz}, J=2.8 \mathrm{~Hz}$, $1 \mathrm{H}$ ), 4.35 (t, $J=5.9 \mathrm{~Hz}, 2 \mathrm{H}$ ), $3.87(\mathrm{t}, J=5.9 \mathrm{~Hz}, 2 \mathrm{H}), 3.77(\mathrm{~s}, 3 \mathrm{H})$, 2.72 (s, 3H), 2.13 (quin, $J=5.9 \mathrm{~Hz}, 2 \mathrm{H}$ ). ${ }^{13} \mathrm{C} \mathrm{NMR}\left(75 \mathrm{MHz}, \mathrm{CDCl}_{3}\right) \delta$ 159.2, 157.7, 154.3, 154.0, 149.4, 133.6, 129.2, 128.7, 126.4, 124.8, 124.6, 122.0, 112.4, 109.4, 107.4, 70.3, 55.6, 51.5, 29.7, 25.5. IR neat vmax $/ \mathrm{cm}^{-1}: 3050,2979,1562,1454$. HRMS calcd for $\mathrm{C}_{20} \mathrm{H}_{21} \mathrm{~N}_{2} \mathrm{O}_{2}[\mathrm{M}+\mathrm{H}]^{+}: 321.1603$ cal., obsd 321.1610.

\section{General procedure for the synthesis of $\mathbf{1 b}$-e}

In a sealed tube were stirred at $130{ }^{\circ} \mathrm{C}$ for $12 \mathrm{~h}, \mathrm{Pd}_{2} \mathrm{dba}_{3}-\mathrm{CHCl}_{3}(13$ $\mathrm{mg}, 0.01 \mathrm{mmol}$ ), Xantphos (15 mg, $0.02 \mathrm{mmol}$ ), NaOtBu (53 mg, $0.55 \mathrm{mmol}), 7(70 \mathrm{mg}, 0.25 \mathrm{mmol})$ and the appropriate 4 chloroquinaldine $(0.28 \mathrm{mmol})$ in toluene $(30 \mathrm{~mL})$. After cooling, the solution was filtered on a pad of celite and concentrated. The crude mixture was purified by chromatography on silica gel eluting with cyclohexane/ethyl acetate (95:5 to $90: 10$ ) to give pure $\mathbf{1 b}$-e.

9-(Benzyloxy)-8-methoxy-5-(2-methylquinolin-4-yl)-2,3,4,5-tetrahydro benzo[b][1,4]oxazepine 1b (41\%)

Yellow solid (44 mg, 41\%), m.p. $=158.7-159.2^{\circ} \mathrm{C} .{ }^{1} \mathrm{H}$ NMR $(300$ $\left.\mathrm{MHz}, \mathrm{CDCl}_{3}\right) \delta 8.02(\mathrm{~d}, J=8.3 \mathrm{~Hz}, 1 \mathrm{H}), 7.58-7.33(\mathrm{~m}, 7 \mathrm{H}), 7.18-$ 7.11, (m, 1H), $6.89(\mathrm{~s}, 1 \mathrm{H}), 6.34(\mathrm{~d}, J=8.9 \mathrm{~Hz}, 1 \mathrm{H}), 6.24(\mathrm{~d}, J=8.9$ $\mathrm{Hz}, 1 \mathrm{H}), 5.19(\mathrm{~s}, 2 \mathrm{H}), 4.25$ (t, $J=5.4 \mathrm{~Hz}, 2 \mathrm{H}), 3.80(\mathrm{~m}, 5 \mathrm{H}), 2.74(\mathrm{~s}$, $3 \mathrm{H}$ ), 2.05 (quin, $J=5.4 \mathrm{~Hz}, 2 \mathrm{H}) .{ }^{13} \mathrm{C} \mathrm{NMR}\left(75 \mathrm{MHz}, \mathrm{CDCl}_{3}\right) \delta 158.5$, $154.4,151.5,148.3,147.4,140.2,137.6,134.7,129.3,128.7$ (2), 128.2 (2), 128.0, 127.8, 124.8, 124.62, 121.50, 119.91, 111.39, $106.54,75.29,70.25,56.07,51.13,29.01,24.91$. IR neat $\mathrm{vmax} / \mathrm{cm}^{-1}$ : $3068,2718,1544$, 1374. HRMS calcd for $\mathrm{C}_{27} \mathrm{H}_{27} \mathrm{~N}_{2} \mathrm{O}_{3}[\mathrm{M}+\mathrm{H}]^{+}$: 427.2022, obsd 427.2018.

4-(9-(Benzyloxy)-8-methoxy-3,4-dihydrobenzo[b][1,4]oxazepin-5(2H)yl) quinoline-2-carbonitrile 1c (19\%)

Yellow solid $(21 \mathrm{mg}, 19 \%)$, m.p. $=137.5-137.9^{\circ} \mathrm{C} .{ }^{1} \mathrm{H}$ NMR $(300$ $\left.\mathrm{MHz}, \mathrm{CDCl}_{3}\right) \delta 7.92(\mathrm{~d}, J=8.5 \mathrm{~Hz}, 1 \mathrm{H}), 7.52(\mathrm{t}, J=8.2 \mathrm{~Hz}, 1 \mathrm{H}), 7.44$ $(\mathrm{d}, \mathrm{J}=7.9 \mathrm{~Hz}, 2 \mathrm{H}), 7.36-7.28(\mathrm{~m}, 3 \mathrm{H}), 7.19-7.11(\mathrm{~m}, 3 \mathrm{H}), 6.27(\mathrm{~d}$, $J=8.9 \mathrm{~Hz}, 1 \mathrm{H}), 6.15(\mathrm{~d}, J=8.9 \mathrm{~Hz}, 1 \mathrm{H}), 5.10(\mathrm{~s}, 2 \mathrm{H}), 4.12$ (t, $J=5.4$ $\mathrm{Hz}, 2 \mathrm{H}), 3.70(\mathrm{~m}, 5 \mathrm{H}), 1.95$ (quin, $J=5.4 \mathrm{~Hz}, 2 \mathrm{H}) .{ }^{13} \mathrm{C}$ NMR $(75 \mathrm{MHz}$, $\left.\mathrm{CDCl}_{3}\right) \delta 154.6,152.2,149.9,140.3,137.5,134.0,133.7,130.2$, $129.8,128.8$ (2), 128.3 (2), 128.1, 127.3, 124.9, 123.4, 120.2, 118.0, $112.5,106.6,75.3,70.1,56.1,51.0,28.5$, one $C$ not seen. IR neat $v \max / \mathrm{cm}^{-1}: 2958,2853,1928,1371,1215$. HRMS calcd for $\mathrm{C}_{27} \mathrm{H}_{24} \mathrm{~N}_{3} \mathrm{O}_{3}[\mathrm{M}+\mathrm{H}]^{+}:$438.1818, obsd 438.1814 .

9-(Benzyloxy)-8-methoxy-5-(2-methyl-6-nitroquinolin-4-yl)-2,3,4,5tetrahydrobenzo[b][1,4]oxazepine 1d (22\%)

Yellow solid (26 mg, 22\%), m.p. $=152.4-154.1^{\circ} \mathrm{C} .{ }^{1} \mathrm{H}$ NMR $(300$ $\left.\mathrm{MHz}, \mathrm{CDCl}_{3}\right) \delta 8.36(\mathrm{~s}, 1 \mathrm{H}), 8.17(\mathrm{~d}, J=9.1 \mathrm{~Hz}, 1 \mathrm{H}), 7.87(\mathrm{~d}, J=9.2$ $\mathrm{Hz}, 1 \mathrm{H}), 7.50$ (d, J = 7.2 Hz, 2H), $7.32(\mathrm{~m}, 3 \mathrm{H}), 6.83(\mathrm{~s}, 1 \mathrm{H}), 6.32$ (d, $J=8.9 \mathrm{~Hz}, 1 \mathrm{H}), 6.24(\mathrm{~d}, J=8.9 \mathrm{~Hz}, 1 \mathrm{H}), 5.11(\mathrm{~s}, 2 \mathrm{H}), 4.21(\mathrm{t}, J=5.3$ $\mathrm{Hz}, 2 \mathrm{H}), 3.73(\mathrm{~m}, 5 \mathrm{H}), 2.63(\mathrm{~s}, 3 \mathrm{H}), 2.01$ (quin, $J=5.3 \mathrm{~Hz}, 2 \mathrm{H}) .{ }^{13} \mathrm{C}$ NMR $\left(75 \mathrm{MHz}, \mathrm{CDCl}_{3}\right) \delta 163.2,154.9,152.6,152.3,148.1,143.3$, $141.4,137.9,133.8,130.3,128.5$ (2), 128.3 (2), 127.9, 122.4, 122.3, $120.3,120.3,111.5,107.1,76.0,70.3,56.2,50.9,28.5,25.9$. IR neat vmax $/ \mathrm{cm}^{-1}: 3122,2923,1614,1239$. HRMS calcd for $\mathrm{C}_{27} \mathrm{H}_{26} \mathrm{~N}_{3} \mathrm{O}_{5}$ $[\mathrm{M}+\mathrm{H}]^{+}:$472.1872, obsd 472.1868.

9-(Benzyloxy)-5-(6-chloro-2-methylquinolin-4-yl)-8-methoxy-2,3,4,5tetrahydrobenzo[b][1,4]oxazepine 1e (16\%)

Yellow solid (18 mg, 16\%), m.p. $=128.4-131.7^{\circ} \mathrm{C} .{ }^{1} \mathrm{H}$ NMR $(300$ $\left.\mathrm{MHz}, \mathrm{CDCl}_{3}\right) \delta 7.72(\mathrm{~d}, \mathrm{~J}=8.9 \mathrm{~Hz}, 1 \mathrm{H}), 7.44-7.18(\mathrm{~m}, 7 \mathrm{H}), 6.76(\mathrm{~s}$,
$1 \mathrm{H}), 6.23(\mathrm{~d}, J=8.9 \mathrm{~Hz}, 1 \mathrm{H}), 6.10(\mathrm{~d}, J=8.9 \mathrm{~Hz}, 1 \mathrm{H}), 5.01(\mathrm{~s}, 2 \mathrm{H})$, $4.08(\mathrm{t}, J=5.7 \mathrm{~Hz}, 2 \mathrm{H}$ ), $3.66(\mathrm{~m}, 5 \mathrm{H}), 2.54(\mathrm{~s}, 3 \mathrm{H}), 1.90$ (quin, $J=$ $5.3 \mathrm{~Hz}, 2 \mathrm{H}) .{ }^{13} \mathrm{C}$ NMR $\left(75 \mathrm{MHz}, \mathrm{CDCl}_{3}\right) \delta 159.5,153.2,151.5,148.0$, $147.9,140.5,137.7,134.7,130.4,130.1,129.7,128.7$ (2), 128.3 (2), 128.0, 123.7, 122.7, 119.9, 112.9, 106.7, 75.7, 70.4, 56.2, 51.2, 29.3, 25.5. IR neat $v \max / \mathrm{cm}^{-1}: 2856,2797,1515,1473,1007$. HRMS calcd for $[\mathrm{M}+\mathrm{H}]^{+} \mathrm{C}_{27} \mathrm{H}_{26} \mathrm{ClN}_{2} \mathrm{O}_{3}: 461.1632$, obsd 461.1625 .

\section{General procedure for the synthesis of $1 \mathrm{f}-\mathrm{i}$}

Benzyled oxazepines $\mathbf{1 b}$-e were mixed with $\mathrm{AICl}_{3}(5 \mathrm{eq})$ in DCM for $12 \mathrm{~h}$ at $\mathrm{rt}$. Then water $(10 \mathrm{~mL})$ was added to the solution which was extracted with DCM $(3 \times 20 \mathrm{~mL})$. After concentration, the crude mixture was purified by chromatography on silica gel eluting with cyclohexane/ethyl acetate (90:10) to give pure compounds $1 \mathrm{f}-\mathrm{i}$.

8-Methoxy-5-(2-methylquinolin-4-yl)-2,3,4,5-tetrahydrobenzo[b][1,4] oxazepin-9-ol $1 \mathbf{f}(92 \%)$

Brown solid (48 mg, 92\%), m.p. $=92.8-97.2^{\circ} \mathrm{C} .{ }^{1} \mathrm{H}$ NMR $(300 \mathrm{MHz}$, $\left.\mathrm{CDCl}_{3}\right) \delta 8.07(\mathrm{~d}, J=8.1 \mathrm{~Hz}, 1 \mathrm{H}), 7.59-7.52(\mathrm{~m}, 2 \mathrm{H}), 7.21(\mathrm{t}, J=$ $7.5 \mathrm{~Hz}, 1 \mathrm{H}), 6.95(\mathrm{~s}, 1 \mathrm{H}), 6.36(\mathrm{~d}, J=8.9 \mathrm{~Hz}, 1 \mathrm{H}), 6.05(\mathrm{~d}, J=8.9$ $\mathrm{Hz}, 1 \mathrm{H}), 4.40$ (t, $J=5.4 \mathrm{~Hz}, 2 \mathrm{H}), 3.91(\mathrm{t}, J=5.4 \mathrm{~Hz}, 2 \mathrm{H}), 3.84(\mathrm{~s}, 3 \mathrm{H})$, 2.77 (s, 3H), 2.18 (quin, $J=5.4 \mathrm{~Hz}, 2 \mathrm{H}$ ), OH not seen. ${ }^{13} \mathrm{C}$ NMR $(75$ $\mathrm{MHz}, \mathrm{CDCl} 3) \delta 156.4,156.3,146.5,143.6,140.4,138.7,132.8$, $131.3,125.6,125.2,124.2,120.2,115.8,109.1,106.6,70.5,56.3$, 51.6, 28.8, 22.3. IR neat $v \mathrm{max} / \mathrm{cm}^{-1}: 3254,2857,1404,1266$. HRMS calcd for $\mathrm{C}_{20} \mathrm{H}_{21} \mathrm{~N}_{2} \mathrm{O}_{3}[\mathrm{M}+\mathrm{H}]^{+}: 337.1552$, obsd 337.1558 .

4-(9-Hydroxy-8-methoxy-3,4-dihydrobenzo[b][1,4]oxazepin-5(2H)yl)quinoline-2-carbonitrile 1g (94\%)

Brown solid (62 mg, 94\%), m.p. $=93.7-95.4^{\circ} \mathrm{C} .{ }^{1} \mathrm{H}$ NMR $(300 \mathrm{MHz}$, $\left.\mathrm{CDCl}_{3}\right) \delta 8.04(\mathrm{~d}, J=8.4 \mathrm{~Hz}, 1 \mathrm{H}), 7.64(\mathrm{t}, J=8.5 \mathrm{~Hz}, 1 \mathrm{H}), 7.56(\mathrm{~d}, J$ $=8.5 \mathrm{~Hz}, 1 \mathrm{H}), 7.36-7.28(\mathrm{~m}, 2 \mathrm{H}), 6.36(\mathrm{~d}, J=8.9 \mathrm{~Hz}, 1 \mathrm{H}), 6.04(\mathrm{~d}$, $J=8.9 \mathrm{~Hz}, 1 \mathrm{H}), 5.82(\mathrm{~s}, 1 \mathrm{H}), 4.39(\mathrm{t}, J=5.1 \mathrm{~Hz}, 2 \mathrm{H}), 3.86(\mathrm{~m}, 5 \mathrm{H})$, 2.19 (quin, $J=5.1 \mathrm{~Hz}, 2 \mathrm{H}) .{ }^{13} \mathrm{C}$ NMR $(75 \mathrm{MHz}, \mathrm{CDCl} 3) \delta 154.6$, $149.9,145.6,140.7,138.4,134.1,133.9,130.3$ (2), 127.5, 124.9, $123.8,117.9,115.4,113.2,106.5,70.8,56.3,51.4,29.6$. IR neat vmax $/ \mathrm{cm}^{-1}: 3397,1649,1563,1342$. HRMS calcd for $\mathrm{C}_{20} \mathrm{H}_{18} \mathrm{~N}_{3} \mathrm{O}_{3}$ $[\mathrm{M}+\mathrm{H}]^{+}: 348.1348$ cal., 348.1352 obsd.

\section{8-Methoxy-5-(2-methyl-6-nitroquinolin-4-yl)-2,3,4,5-tetrahydrobenzo} [b][1,4]oxazepin-9-ol 1h (69\%)

Brown solid (52 mg, 69\%), m.p. $=107.3-108.9{ }^{\circ} \mathrm{C} .{ }^{1} \mathrm{H}$ NMR $(300$ $\left.\mathrm{MHz}, \mathrm{CDCl}_{3}\right) \delta 8.41(\mathrm{~s}, 1 \mathrm{H}), 8.21(\mathrm{~d}, J=9.2 \mathrm{~Hz}, 1 \mathrm{H}), 7.94(\mathrm{~d}, J=9.2$ $\mathrm{Hz}, 1 \mathrm{H}), 6.87(\mathrm{~s}, 1 \mathrm{H}), 6.32(\mathrm{~d}, J=8.9 \mathrm{~Hz}, 1 \mathrm{H}), 6.04(\mathrm{~d}, J=8.8 \mathrm{~Hz}$, $1 \mathrm{H}$ ), 4.33 (t, $J=5.2 \mathrm{~Hz}, 2 \mathrm{H}$ ), 3.85 (t, $J=5.2 \mathrm{~Hz}, 2 \mathrm{H}), 3.78(\mathrm{~s}, 3 \mathrm{H})$, 2.66 (s, 3H), 2.09 (quin, $J=5.2 \mathrm{~Hz}, 2 \mathrm{H}$ ), $\mathrm{OH}$ not seen. ${ }^{13} \mathrm{C}$ NMR $(75$ $\left.\mathrm{MHz}, \mathrm{CDCl}_{3}\right) \delta 162.8,155.3,146.0,143.6,141.2,138.8,137.1$, 133.6, 129.9, 122.7, 122.2, 120.5, 115.4, 112.4, 106.9, 70.9, 57.4, $51.6,29.5,25.5$. IR neat $v \max / \mathrm{cm}^{-1}: 3122,2923,1614,1239$. HRMS calcd for $\mathrm{C}_{20} \mathrm{H}_{20} \mathrm{~N}_{3} \mathrm{O}_{5}[\mathrm{M}+\mathrm{H}]^{+}: 382.1403$, obsd 382.1395 .

5-(6-Chloro-2-methylquinolin-4-yl)-8-methoxy-2,3,4,5-tetrahydrobenzo[b][1,4]oxazepin-9-ol 1i (42\%)

Brown solid (35 mg, 42\%), m.p. $=92.3-94.1^{\circ} \mathrm{C} .{ }^{1} \mathrm{H}$ NMR $(300 \mathrm{MHz}$, $\left.\mathrm{CDCl}_{3}\right) \delta 8.26(\mathrm{~d}, J=9.0 \mathrm{~Hz}, 1 \mathrm{H}), 7.60(\mathrm{dd}, J=8.7 \mathrm{~Hz}, J=2.0 \mathrm{~Hz}$, $1 \mathrm{H}), 7.48(\mathrm{~s}, 1 \mathrm{H}), 6.99(\mathrm{~s}, 1 \mathrm{H}), 6.52(\mathrm{~d}, J=8.9 \mathrm{~Hz}, 1 \mathrm{H}), 6.19(\mathrm{~d}, J=$ $8.8 \mathrm{~Hz}, 1 \mathrm{H}), 4.46(\mathrm{t}, J=5.1 \mathrm{~Hz}, 2 \mathrm{H}), 4.12-3.82(\mathrm{~m}, 5 \mathrm{H}), 2.87(\mathrm{~s}$, $3 \mathrm{H}$ ), $2.35-2.20$ (quin, $J=5.1 \mathrm{~Hz}, 2 \mathrm{H}$ ), OH not seen. ${ }^{13} \mathrm{C}$ NMR (75 $\mathrm{MHz}, \mathrm{CDCl} 3) \delta 158.5,153.9,145.6,140.9,138.6(2 \mathrm{C}), 133.8,130.7$, $130.5,128.9,123.9,122.3,115.1,112.3,106.6,70.9,56.3,51.7$, 
29.7, 24.4. IR neat $v \mathrm{max} / \mathrm{cm}^{-1}: 2897,2789,1493,1254$. HRMS calcd for $\mathrm{C}_{20} \mathrm{H}_{20} \mathrm{CIN}_{2} \mathrm{O}_{3}[\mathrm{M}+\mathrm{H}]^{+}: 370.1084$, obsd. 370.1080 .

\section{8-Methoxy-5-(2-methylquinolin-4-yl)-2,3,4,5-tetrahydrobenzo[b][1,4]} oxazepin-9-yl 2-chloroacetate 1j (45\%)

Oxazepine 1f $(20 \mathrm{mg})$ was added with $\mathrm{NEt}_{3}(16.5 \mu \mathrm{L})$ in DCM $(2 \mathrm{~mL})$ at rt. To this solution was added dropwise $90 \mu \mathrm{L}$ of a 2-chloroacetyl chloride solution $(0.1 \mathrm{~N})$. The resulting was stirred at $\mathrm{rt}$ for $12 \mathrm{~h}$ and then was hydrolyzed with $5 \mathrm{~mL}$ of water. After extraction with DCM $(3 \times 10 \mathrm{~mL})$ and concentration, the crude mixture was purified by chromatography on silica gel eluting with cyclohexane/ethyl acetate (90:10) to give pure oxazepine $\mathbf{1 j}(45 \%)$.

Brown oil (13 mg, 45\%). ${ }^{1} \mathrm{H}$ NMR $\left(300 \mathrm{MHz}, \mathrm{CDCl}_{3}\right) \delta 8.18(\mathrm{~d}, \mathrm{~J}=$ $8.3 \mathrm{~Hz}, 1 \mathrm{H}$ ), $7.60(\mathrm{t}, J=8.3 \mathrm{~Hz}, 1 \mathrm{H}), 7.28-7.21(\mathrm{~m}, 2 \mathrm{H}), 6.79(\mathrm{~s}$, $1 \mathrm{H}), 6.54(\mathrm{~d}, J=8.9 \mathrm{~Hz}, 1 \mathrm{H}), 6.46(\mathrm{~d}, J=9.0 \mathrm{~Hz}, 1 \mathrm{H}), 4.38-4.31(\mathrm{~m}$ $2 \mathrm{H}), 4.02(\mathrm{~s}, 3 \mathrm{H}), 3.94-3.86(\mathrm{~m}, 2 \mathrm{H}), 3.75(\mathrm{~s}, 2 \mathrm{H}), 2.83(\mathrm{~s}, 3 \mathrm{H})$, $2.15(\mathrm{~m}, 2 \mathrm{H}) .{ }^{13} \mathrm{C}$ NMR $\left(75 \mathrm{MHz}, \mathrm{CDCl}_{3}\right) \delta 189.3,158.1,155.0$, 152.0, 146.0, 140.2, 132.7, 130.9, 126.5, 125.7, 125.6, 124.4, 121.5, $119.0,107.7,107.1,70.2,56.3,51.6,40.5,29.7,20.9$. IR neat vmax $/ \mathrm{cm}^{-1}: 3093,2854,1614,1213$. HRMS calcd for $\mathrm{C}_{22} \mathrm{H}_{22} \mathrm{~N}_{2} \mathrm{O}_{4} \mathrm{Cl}$ $[\mathrm{M}+\mathrm{H}]^{+}:$413.1268, obsd 413.1273.

\section{Biology}

Cell culture and proliferation assay

Cancer cell lines were obtained from the American type Culture Collection (Rockville, MD) and were cultured according to the supplier's instructions. Briefly, HCT116, U87, K562 and MCF7 cells were grown in RPMI 1640 containing $10 \%$ FCS and $1 \%$ glutamine. A549 lung carcinoma, cells were grown in Dulbecco minimal essential medium (DMEM) containing $4.5 \mathrm{~g} / \mathrm{L}$ glucose supplemented with $10 \%$ FCS and $1 \%$ glutamine. All cell lines were maintained at $37^{\circ} \mathrm{C}$ in a humidified atmosphere containing $5 \% \mathrm{CO}_{2}$. The maximum number of passages for each cell line was eight (8). Cell viability was assessed using Promega CellTiter-Blue TM reagent according to the manufacturer's instructions. Cells were seeded in 96 -well plates $(5 \times$ 103 cells/well) containing $50 \mu \mathrm{L}$ growth medium. After $24 \mathrm{~h}$ of culture the cells were supplemented with $50 \mu \mathrm{L}$ of the tested compound dissolved in DMSO (less than $0.1 \%$ in each preparation). After $72 \mathrm{~h}$ of incubation, $20 \mu \mathrm{L}$ of resazurin was added for $2 \mathrm{~h}$ (the supplier's protocol recommends 1-4 h) before recording fluorescence ( $\lambda$ ex $=$ $560 \mathrm{~nm}, \lambda \mathrm{em}=590 \mathrm{~nm}$ ) using a Victor microtiter plate fluorimeter (Perkin-Elmer, USA). The $\mathrm{IC}_{50}$ corresponds to the concentration of the tested compound that caused a decrease of $50 \%$ in fluorescence of drug treated cells compared with untreated cells. For $\mathrm{IC}_{50}$ determination, all products $\mathbf{1 a - j}$ were tested at 10 different concentrations, each concentration being tested in triplicate.

\section{Tubulin binding assay}

Sheep brain tubulin was purified according to the method of Shelanski ${ }^{[34]}$ by two cycles of assembly-disassembly and then dissolved in the assembly buffer containing $0.1 \mathrm{M}$ MES, $0.5 \mathrm{mM}$ $\mathrm{MgCl}_{2}, 1 \mathrm{mM}$ EGTA, and $1 \mathrm{mM}$ GTP, pH 6.6 (the concentration of tubulin was about $2-3 \mathrm{mg} / \mathrm{mL}$ ). Tubulin assembly was monitored by fluorescence according to reported procedure ${ }^{[35]}$ using DAPI as fluorescent molecule. Assays were realized on 96-well plates prepared with Biomek NKMC and Biomek 3000 from Beckman Coulter and read at $37^{\circ} \mathrm{C}$ on Wallac Victor fluorimeter from Perkin Elmer. The $\mathrm{IC}_{50}$ value of each compound was determined as the concentration which decreased the maximum assembly rate of tubulin by $50 \%$ compared to the rate in the absence of compound.
The $\mathrm{IC}_{50}$ values for all compounds were compared to the $\mathrm{IC}_{50}$ of isoCA-4 and measured the same day under the same conditions.

Cell cycle analysis

Exponentially growing cancer K562 and HCT116 cells were incubated with $\mathbf{1 g}$ at different concentrations (1 and $5 \mathrm{nM}$ ) or in DMSO alone for $24 \mathrm{~h}$. Cell-cycle profiles were determined by flow cytometry on a FC500 flow cytometer (Beckman-Coulter, France) as described previously. ${ }^{[36]}$

\section{Molecular modeling}

Atomic coordinates for tubulin $\alpha, \beta$-dimer were retrieved from the Protein Data Bank (accession code $6 \mathrm{H} 9 \mathrm{~B}){ }^{\left[{ }^{21]}\right.}$ Missing hydrogen atoms were added using the Dock Prep module from the UCSF Chimera v1.13 software package,$^{[37]}$ and atoms from the ligand cocrystallized in the colchicine binding at the interface between chains $\mathrm{C}$ and D were deleted. Coordinates for a low-energy starting conformer of compound $\mathbf{1 g}$ were obtained using the conformers function from MarvinSketch v19.12 software package ${ }^{[38]}$ with default parameters. Molecular docking was performed using AutoDock Vina v1.1.2 software package ${ }^{[39]}$ with default parameters and the binding site defined as the box circumscribed to all the protein residues in contact with the co-crystallized ligand. Analysis and depiction of poses were performed using UCSF Chimera v1.13 software package. ${ }^{[37]}$

\section{Acknowledgements}

The authors gratefully acknowledge support of this project by CNRS and University Paris-Saclay. Ilhem Khelifi (I.K.) and Shannon Pecnard (S.P.) thank the MRES (Ministère de la Recherche et de l'Enseignement Supérieur) and La Ligue Contre le Cancer for their Ph.D. fundings.

\section{Conflict of interest statement}

The authors declare no conflict of interest.

Keywords: cancer $\bullet$ cytotoxicity $\bullet$ isoCA-4 - oxazepine $\bullet$ quinoline

[1] G. R. Pettit, S. B. Singh, E. Hamel, C. M. Lin, D. S. Alberts, D. GarciaKendall, Experientia 1989, 45, 209-211.

[2] C. M. Lin, H. H. Ho, G. R. Pettit, E. Hamel, Biochemistry 1989, 28 , 6984-6991.

[3] A. T. Mc Gown, B. W. Fox, Cancer Chemother. Pharmacol. 1990, 26 , 79-81.

[4] G. M. Tozer, V. E. Prise, J. Wilson, R. J. Locke, B. Vojnovic, M. R. Stratford, M. F. Dennis, D. J. Chaplin, Cancer Res. 1999, 59, 16261634.

[5] G. M. Tozer, C. Kanthou, C. S. Parkins, S. A. Hill, Int. J. Exp. Pathol. 2002, 83, 21-38.

[6] G. G. Dark, S. A. Hill, V. E. Prise, G. M. Tozer, G. R. Pettit, D. J. Chaplin, Cancer Res. 1997, 57, 1829-1834.

[7] www.mateon.com

[8] K. Ohsumi, T. Hatanaka, R. Fujita, R.Nakagawa, Y. Fukuda, Y. Nihei, Y. Suga, Y. Morinaga, Y. Akiyama, T. Tsuji, Bioorg. Med. Chem. Lett. 1998, 8, 3153-3158. 
[9] S. Aprile, E. Del Grosso, G. C. Tron, G. Grosa, Drug Metab. Dispos. 2007, 35, 2252-2261.

[10] O. Provot, A. Hamze, J. F. Peyrat, J. D. Brion, M. Alami, Anticancer Agents Med. Chem. 2013, 13, 1614-1635.

[11] S. Messaoudi, B. Tréguier, A. Hamze, O. Provot, J. F. Peyrat, J. R. Rodrigo De Losada, J. M. Liu, J. Bignon, J. Wdzieczak-Bakala, S. Thoret, J. Dubois, J. D. Brion, M. Alami, J. Med. Chem. 2009, 52, 45384542.

[12] A. Hamze, A. Giraud, S. Messaoudi, O. Provot, J. F. Peyrat, J. Bignon, J. M. Liu, J. Wdzieczak-Bakala, S. Thoret, J. Dubois, J. D. Brion, M. Alami, ChemMedChem 2009, 4, 1912-1924.

[13] S. Messaoudi, A. Hamze, O. Provot, B. Tréguier, J. Rodrigo De Losada, J. Bignon, J.-M. Liu, J. Wdzieczak-Bakala, S. Thoret, J. Dubois, J.-D. Brion, M. Alami, ChemMedChem 2011, 6, 488-497.

[14] M. A. Soussi, O. Provot, G. Bernadat, J. Bignon, J. Wdzieczak-Bakala, D. Desravines, J. Dubois, J. D Brion, S. Messaoudi, M. Alami, Eur. J. Med. Chem. 2014, 78, 178-189.

[15] A. Hamze, E. Rasolofonjatovo, O. Provot, C. Mousset, D. Veau, J. Rodrigo, J. Bignon, J. M; Liu, J. Wdzieczak-Bakala, S. Thoret, J. Dubois, J. D. Brion, M. Alami, ChemMedChem 2011, 6, 2179-2191.

[16] E. Rasolofonjatovo, O. Provot, A. Hamze, J. Rodrigo, J. Bignon, J. Wdzieczak-Bakala, D. Desravines, J. Dubois, J. D. Brion, M. Alami, Eur. J. Med. Chem. 2012, 52, 22-32.

[17] D. Renko, E. Rasolofonjatovo, O. Provot, J. Bignon, J. Rodrigo, J. Dubois, J. D. Brion, A. Hamze, M. Alami, Eur. J. Med. Chem. 2015, 90 834-844.

[18] E. Rasolofonjatovo, O. Provot, A. Hamze, J. Rodrigo, J. Bignon, J. Wdzieczak-Bakala, C. Lenoir, D. Desravines, J. Dubois, J. D. Brion, M. Alami, Eur. J. Med. Chem. 2013, 62, 28-39.

[19 ] M. A. Soussi, O. Provot, G. Bernadat, J. Bignon, D. Desravines, J. Dubois, J. D. Brion, S. Messaoudi, M. Alami, ChemMedChem 2015, 10, 1392-1402.

[20 ] I. Khelifi, T. Naret, D. Renko, A. Hamze, G. Bernadat, J. Bignon, C. Lenoir, J. Dubois, J. D.; Brion, O. Provot, M. Alami, Eur. J. Med. Chem. 2017, 127, 1025-1034.

[21] T. Naret, I. Khelifi, O. Provot, J. Bignon, H. Levaique, J. Dubois, M. Souce, A. Kasselouri, A. Deroussent, A. Paci, P. Varela, B. Gigant, M. Alami, A. Hamze, J. Med. Chem. 2019, 62, 1902-1916.

[22] I. Khelifi, T. Naret, T.; A. Hamze, J. Bignon, H. Levaique, C. Garcia, J. Dubois, O. Provot, M. Alami, Eur. J. Med. Chem., 2019, 168, 176-188.

[23] Y. Zhou, W. Yan, D. Cao, M. Shao, D. Li, F. Wang, Z. Yang, Y. Chen, L. He, T. Wang, M. Shen, L. Chen, Eur. J. Med. Chem. 2017, 138, 11141125.

[24] X.-F. Wang, F. Guan, E. Ohkoshi, W. Guo, L. Wang, D.-Q. Zhu, S.-B. Wang, L.-T. Wang, E. Hamel, D. Yang, L. Li, K. Qian, S. L. MorrisNatschke, S. Yuan, K.-H. Lee, L. Xie, J. Med. Chem. 2014, 57, 13901402.

[25] X.-F. Wang, S.-B. Wang, E. Ohkoshi, L.-T. Wang, E. Hamel, K. Qian, S.L. Morris-Natschke, K.-H. Lee, L. Xie. Eur. J. Med. Chem. 2013, 67, 196-207.

[26] S. Kasibhatla, V. Baichwal, S. X. Cai, B. Roth, I. Skvortsova, S. Skvortsov, P. Lukas, N. M. English, N. Sirisoma, J. Drewe, A. Pervin, B. Tseng, R. O. Carlson, C. M. Pleiman, Cancer Res. 2007, 67, 5865-5871

[27] Y. Ana, E. Leea, Y. Yu, J. Yun, M., Y. Lee, J. S. Kang, W.-Y. Kim, R. Jeon, Bioorg. Med. Chem. Lett. 2016, 26, 3076-3072.

[28] Amine 6 was found to be unstable on $\mathrm{SiO}_{2}$ gel column and was used without purification for the next cyclization step.

[29] S., Qingyan, Z. Weidong, Y., Hu, WO2015/109080 A1.

[30] A. Giraud, O. Provot, A. Hamze, J.D. Brion, M. Alami, Tetrahedron Lett. 2008, 49, 1107-1110.
[31] In the majority of cases concerning isoCA-4 analogues, a $\mathrm{OH}$ group leads to the more cytotoxic compounds even if other small groups are permitted with slightly inferior cytotoxicities. For a review concerning SARs on isoCA-4 see: M. Alami, A. Hamze, O. Provot, Eur. J. Med. Chem. 2020, 190, 112110.

[32] The basis for this difference has been attributed to intracellular retention of these compounds, leading to higher intracellular concentrations (see: M. A. Jordan, K. Wendell, S. Gardiner, W. Brent Derry, H. Copp, L. Wilson, Death Cancer Res. 1996, 56, 816-825. Moreover, the tubulin polymerization test consists in a rapid turbidimetric assay that examines instantaneous effects on polymerization. The difference between long-term continuous treatment in the cell-based assay $(72 \mathrm{~h}$ ) and instant measurements explain such concentration differences.[see: G. C. Tron, T. Pirali, G. Sorba, F. Pagliai, S. Busacca, A. A. Genazzani, J. Med. Chem., 2006, 49, 30333044.

[33] Analysis of the effects of $\mathbf{1 g}$ on the cell cycle regulation can explain in part, the mode of action of this compound on cancer cells. It is reasonable to think that this mode of action will be the same on the five tested cell lines and that is not necessary to choose the most sensitive cell line (U87) since we used concentrations close to the $\mathrm{IC}_{50}$ values to achieve these cell cycle experiments. IsoCA4 was used as a positive control and the results obtained are identical to those previously published.

[34] M. L. Shelanski, F. Gaskin, C. R. Cantor, Proc. Natl. Acad. Sci. USA 1973, 70, 765-768.

[35] D. M. Barron, S. K. Chatterjee, R. Ravindra, R. Roof, E. Baloglu, D. G. I. Kingston, S. Bane, Anal. Biochem. 2003, 315, 49-56.

[36] C. Venot, M. Maratrat, C. Dureuil, E. Conseiller, L. Bracco, L. Debussche, EMBO J. 1998, 17, 4668-4679.

[37] E. F. Pettersen, T. D. Goddard, C. C. Huang, G. S. Couch, D. M. Greenblatt, E. C. Meng, T. E. Ferrin, J. Comput. Chem. 2004, 25, 16051612.

[38] http://www.chemaxon.com

[39] O. Trott, A. J. Olson, J. Comput. Chem. 2010, 31, 455-461. 


\section{Entry for the Table of Contents}

Insert graphic for Table of Contents here. ((Please ensure your graphic is in one of following formats))

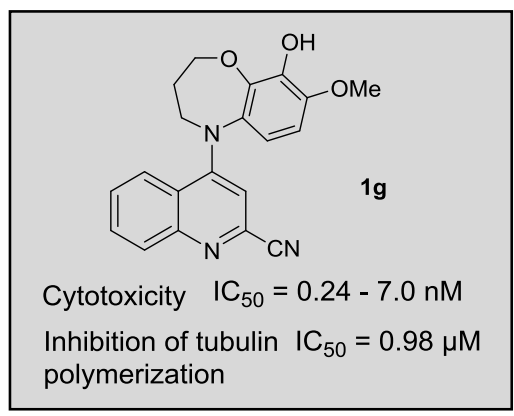

A series of novel benzo[ $b][1,4]$ oxazepines was synthesized and $\mathbf{1 g}$ was found to be highly cytotoxic at a nanomolar level against 5 human cancer cell lines and inhibited tubulin assembly. Oxazepinol $\mathbf{1 g}$ block the cellular cycle in the G2/M phase at a concentration of $5 \mathrm{nM}$. A Molecular docking study shows that $1 \mathrm{~g}$ perfectly overlays with isoCA-4 in $\beta$-tubulin at the colchicine binding site.

\footnotetext{
Ilhem Khelifi, ${ }^{[a]}$ Shannon Pecnard, ${ }^{[a]}$ Guillaume Bernadat,${ }^{[a]}$ Jérome Bignon, ${ }^{[b]}$ Hélène Levaique,${ }^{[b]}$ Joëlle Dubois, ${ }^{[b]}$ Olivier Provot ${ }^{\star[a]}$, Mouad Alami ${ }^{\star[a]}$

${ }^{[a]}$ Université Paris-Saclay, CNRS, BioCIS, 92290 Châtenay-Malabry, France

${ }^{[b]}$ Institut de Chimie des Substances Naturelles, UPR 2301, CNRS, avenue de la terrasse, F-91198 Gif sur Yvette, France
} 